\title{
A new species of Mesopolobus (Hymenoptera, Pteromalidae) from black locust crops
}

\author{
Zoltán LÁSZLÓ ${ }^{1, *}$, K. Tímea LAKATOS ${ }^{2} \&$ Avar-Lehel DÉNES ${ }^{1,3}$ \\ ${ }^{1}$ Hungarian Department of Biology and Ecology, Babeş-Bolyai Universitfy, Str. Clinicilor nr. 5-7, \\ 400006 Cluj-Napoca, Romania. \\ ${ }^{2}$ Department of Ecology, University of Debrecen, Debrecen, Egyetem square 1, H-4032, Hungary. \\ ${ }^{3}$ Interdisciplinary Research Institute on Bio-Nano-Sciences of Babeș-Bolyai University, \\ Treboniu Laurian 42, 400271, Cluj-Napoca Romania. \\ *Corresponding author: laszlozoltan@gmail.com \\ 2Email: lakatos.k.timea@gmail.com \\ ${ }^{3}$ Email: avar.lehel@gmail.com \\ ${ }^{1}$ urn:lsid:zoobank.org:author:FBD0C90D-5590-410D-BA8B-24D812D43DEC
${ }^{2}$ urn:Isid:zoobank.org:author:25A60BB2-ED2D-47E2-8950-89DF12B2B742
${ }^{3}$ urn:lsid:zoobank.org:author:046BBBD0-2DD9-497B-9E36-CEC594C0EE35
}

\begin{abstract}
A new species of the genus Mesopolobus Westwood, 1833, Mesopolobus robiniae Lakatos \& László sp. nov., is described and illustrated from east-central Europe (Romania and Hungary). The species was reared from black locust (Robinia pseudoacacia) seedpod samples, where it most likely parasitizes the black locust's seed predator Bruchophagus robiniae Zerova, 1970. Here we present the new species and report on its ecological relationships within the European seed predator community of black locust. We also give details regarding type material and type locality, a detailed description with images, a differential diagnosis of the new species, and a modification to the identification key published by Graham (1969), that distinguishes this new species from closely related species. In addition, we provide information on the distribution, biology and results of barcoding analysis. We also provide the DNA sequence data to complement the morphological taxonomy.
\end{abstract}

Keywords. New species description, black locust seed predation, seed predator parasitoid, morphometry, multivariate ratio analysis.

László Z., Lakatos K.T. \& Dénes A.-L. 2021. A new species of Mesopolobus (Hymenoptera, Pteromalidae) from black locust crops. European Journal of Taxonomy 740: 118-137. https://doi.org/10.5852/ejt.2021.740.1285

\section{Introduction}

In the last century, the black locust (Robinia pseudoacacia L.) became a characteristic component feature of the Central and Eastern European landscape (Vítková et al. 2017). Its positive economic, but negative environmental impacts led to conflicts between nature conservationists, forestry workers, urban planning experts, beekeepers and the public (Benesperi et al. 2012; Dickie et al. 2014; Sádlo et al. 
2017). As current legislation will determine the future distribution of black locust, we need detailed knowledge, not only from the viewpoint of the forestry and economy, but also from the viewpoint of the species' potential associates, like herbivorous insects and their community (Kleinbauer et al. 2010).

The invasive history of black locust follows the characteristic pathway of introduced crops with an initial phase when presumably several independent introductions occurred from North America, which ceased for a long period, then were followed by frequent plantings and a rapid invasion in the wild, resulting in its widespread distribution of today (DAISIE 2009). The invasion of black locust in Central and Eastern Europe was facilitated by extensive plantings, due to the wood's long-term quality, resistance to insects and fungi, rapid growth, easy propagation, and ability to stabilize soils (Vítková et al. 2017).

When replacing native vegetation, the black locust reduces local biodiversity (Hanzelka \& Reif 2015). Endangered light-demanding plants and invertebrates are threatened by its appearance through reducing light to plants growing beneath the canopy and above the forest floor, and changing the microclimate and soil quality (Lazzaro et al. 2018). These impacts can have effects throughout the food chain, by depriving birds of their insect prey, which depend on the plants that have been wiped out by the black locust (Hanzelka \& Reif 2015). One of the central problems regarding black locust colonization is its capacity to rapidly increase soil nutrient concentration and to alter soil chemical properties which conditions then facilitate invasion by other non-native nitrophilous plant species (Enescu \& Dănescu 2013).

Because of the wide distribution and negative environmental impacts of black locust, an important management tool for invasive populations is limiting their propagation (Redei et al. 2001). The crops of black locust are attacked by several pests, among which the seed predators can have a major impact (Zerova 1970; Perju 1998). Bruchophagus robiniae Zerova, 1970 (Hymenoptera: Chalcidoidea: Eurytomidae) is a pre-dispersal seed predator, monophagous on black locust seeds (Perju 1998). As with other Bruchophagus Ashmead, 1888 species, each B. robiniae individual feeds and develops inside one infested seed, so each seed wasp consumes only one seed and each seed houses only one seed wasp (Lakatos et al. 2018). This seed predator has a component community comprising several species, including parasitoid wasps (Lakatos et al. 2016, 2018).

One member of the Bruchophagus robiniae - black locust seed predator community belongs to the genus Mesopolobus Westwood, 1833, a group of parasitoid wasps in Pteromalidae Dalman, 1820 (Hymenoptera: Chalcidoidea) containing more than 120 described species (Noyes 2020), over 60 of which are present in Europe (http://www.fauna-eu.org/). Species of this genus have a wide host range, although several species are known to be host-specific on galls (Diptera: Cecidomyiidae, Hymenoptera: Cynipidae), bark beetles (Scolytinae), seed predators (Lepidoptera; Coleoptera: Curculionidae, Bruchinae; Hymenoptera: Eurytomidae), etc. (Bouček \& Rasplus 1991; Noyes 2020). Several Eurytomidae Walker, 1832 species, such as Bruchophagus gibbus (Boheman, 1836) has Mesopolobus sp. parasitoids (Noyes 2020), and several Mesopolobus species are parasitoids of pests on oilseed rape (Brassica napus L.), on alfalfa (Medicago sativa L.), or on Norway spruce (Picea abies L.) (Noyes 2020).

Mesopolobus is a taxonomically complex genus, considering the high number of species belonging to this genus. European Mesopolobus were revised by Hans von Rosen (von Rosen 1958, 1959, 1960, 1961), who synonymized species from multiple genera (Amblymerus Walker, 1834; Eutelus Walker, 1834; Platyterma Walker, 1834) under Mesopolobus. The last revision of the Mesopolobus genus for the Western Palearctic was written by Graham (1969). Later studies dealing with Mesopolobus parasitoids of certain host groups have provided further clarifications of species synonymies, notably parasitoids of gall inducing Cynipidae Latreille, 1802 on Quercus sp. (Askew 1961; Nieves-Aldrey 1983; PujadeVillar 1993) and of seed weevils associated with Brassicaceae (Baur et al. 2007). Since the latest generic 
revision (Graham 1969) several new species have been described from Asia (e.g., Narendran et al. 2011; Xiao et al. 2016) and North-America (e.g., Doganlar 1979).

The identification of Mesopolobus species emerged from black locust crops was based on the most detailed identification key up to date provided by Graham (1969). Using Graham's keys a number of characters (fore wing marginal vein length ratio to stigmal vein length, number of anelli and funicular segments, position of toruli to anterior margin of clypeus and to median ocellus, pilosity of the basal cell of fore wing, position of hypopygium tip along the metasoma) led us to key couplet 16 (Graham 1969: 643), where based on two character combinations, namely metasoma length ratio to head plus mesosoma length and metasoma breadth, which did not match our specimens. This suggested the specimens reared from the black locust pods were not represented in the keys, and were likely undescribed. We thus studied several Mesopolobus species represented in the keys and compared them morphometrically to the Mesopolobus females emerged from black locust seed pods. This approach provides robust insight into Mesopolobus morphology, which may play a major role in resolving the species delimitations in biocontrol studies. Complementing the morphometric study, we also analyzed $m t \mathrm{COI}$ sequences of the emerged Mesopolobus females from black locust pods, and compared them to the available $m t \mathrm{COI}$ sequences from the BOLD System and NCBI databases.

Our objectives were the following: i) to identify those morphometric characters that give the best discrimination of the females emerged from black locust seedpods from other Mesopolobus species. ii) to calculate the genetic distance values between the $m t \mathrm{COI}$ sequence of the females emerged from black locust and the other Mesopolobus species. iii) to describe the females and the males of the species that emerged from black locust seedpods.

\section{Material and methods}

To gather information about black locust seedpod insect inhabitants we collected seedpod samples in black locust plantations and patches for four years, in the early spring of 2009 in Romania and between 2013-2015 in Romania and Hungary (Table 1). Samples were placed in plastic cups, containing 20100 seedpods and covered with punched plastic wrap. Samples were kept in a covered balcony with a temperature and humidity close to outdoors at Babeș-Bolyai University (Cluj-Napoca, Romania) and at University of Debrecen (Debrecen, Hungary). Emerged individuals were monitored and collected monthly from seedpod samples for a year, and stored in $70 \%$ ethanol. The dominant emerging species were the seed predator of black locust seeds, Bruchophagus robiniae, and its parasitoid, the undescribed Mesopolobus species (Lakatos et al. 2018).

Identification and description of the emerged Mesopolobus species have been made under an Olympus SZ51 binocular microscope, with an $80 \times$ magnification and LED lighting. Images were produced by a Canon EOS 600D and a Canon EF $100 \mathrm{~mm} \mathrm{f} / 2.8$ USM Macro Lens. Morphological nomenclature follows Graham (1969). The provided identification key is modified from the keys to genus Mesopolobus of Graham (1969). Type material is deposited in the Museum of Zoology, Babeş-Bolyai University, ClujNapoca (MZBBU). Specimen identification codes: holotype-MZBBU HYM000011; 14 paratypesMZBBU HYM000012 to HYM000025, measured female specimens: HYM000026 to HYM000039.

For morphological comparison several specimens were loaned from different museums. The specimens of Mesopolobus amaenus (Walker, 1834), M. apicalis (syn. thomsonii) (Thompson, 1878), M. aspilus (syn. elongates) (Walker, 1835), M. diffinis (Walker, 1834), M. dubius (Walker, 1834), M. fasciiventris Westwood, 1833, M. semiclavatus (Ratzeburg, 1848) and M. typographi (Ruschka, 1924) were loaned from the Hungarian Natural History Museum, Budapest, Hungary (HNHM). Specimens of M. verditer (Norton, 1869), M. mediterraneus (Mayr, 1903), M. tibialis (Westwood, 1833) and M. xanthocerus (Thomson, 1878) were loaned from the Natural History Museum, London, United Kingdom (NHM). 
Table 1. Collection dates, location and number of M. robiniae Lakatos \& László sp. nov. individuals. Abbreviations: $\mathrm{BH}=$ Bihor County, Romania; $\mathrm{CJ}=$ Cluj County, Romania; $\mathrm{HB}=$ Hajdú-Bihar County, Hungary.

\begin{tabular}{lcccccc}
\hline Collection date & Location & Northing & Easting & $\mathbf{N}$ & $\mathbf{N}$ o & N + \\
\hline 2009 & BH & 47.098202 & 21.975355 & 9 & 7 & 2 \\
2009 & CJ & 46.827366 & 23.629258 & 44 & 16 & 28 \\
2013 & BH & 47.098202 & 21.975355 & 4 & 0 & 4 \\
2013 & CJ & 46.801433 & 23.611995 & 26 & 12 & 14 \\
2014 & BH & 47.098202 & 21.975355 & 69 & 35 & 34 \\
2014 & CJ & 46.801433 & 23.611995 & 104 & 62 & 42 \\
2014 & HB & 47.554773 & 21.591610 & 58 & 48 & 10 \\
2015 & BH & 47.098202 & 21.975355 & 16 & 8 & 8 \\
2015 & CJ & 46.801433 & 23.611995 & 23 & 13 & 10 \\
2015 & HB & 47.554773 & 21.591610 & 30 & 14 & 16 \\
\hline
\end{tabular}

One female specimen of $M$. longicollis Graham, 1969 was measured using ImageJ from photographs of the type provided by Oxford University Museum of Natural History.

We measured 19 morphometric variables, corresponding to those used in the taxonomy of Pteromalidae for calculating typically used ratios (e.g., Graham, 1969) (Table 2), on a total of 55 dry-mounted Mesopolobus females belonging to the new species (Supp. file 1). Measurements were made with an Olympus SZ51 stereo microscope (objective: 110AL2X; eyepiece: WHSZ10X) under $60 \times$ and $80 \times$ magnification using a calibrated eye-piece micrometer $(2.5 \mathrm{~mm}$ subdivided into 100 units). For all measurements we ensured that the points of reference were equidistant from the objective of the microscope.

Body ratios of Mesopolobus female specimens were analysed using the Multivariate Ratio Analysis (MRA) tool (Baur \& Leuenberger 2011). Variation structure of Mesopolobus specimens was analysed by PCA in shape space to identify the principal components accounting for the variation. For the visualization of each character's contribution we used PCA ratio spectrum. Body ratios with best discriminant power were determined using the LDA ratio extractor (Baur \& Leuenberger 2011). Analyses were made with R statistical software ver. 3.6.3 (R Core Team 2020).

Genomic DNA was extracted from three individuals using DNeasy Blood and Tissue kits (Qiagen Inc., Valencia, CA), following the protocol provided by the manufacturer. Mitochondrial cytochrome c oxidase subunit I (COI) sequences were amplified using the standard LCO1490 and HCO2198 primer pair (Folmer et al. 1994) in a $50 \mu 1$ reaction volume at a $45^{\circ} \mathrm{C}$ annealing temperature. PCR products were purified with the Wizard SV Gel and PCR Clean-Up System (Promega, USA) and sent for sequencing to Macrogen Inc. (Korea).

Sequences were downloaded and verified with the Basic Local Alignment Search Tool (BLAST) (Johnson et al. 2008). Further, sequences for all available Mesopolobus species were also downloaded from the NCBI database and the BOLD System (for reference numbers see Fig. 2). The sequences were aligned using a Clustal W algorithm (Thompson et al. 1994) in BioEdit (Hall 1999). A phylogenetic tree was inferred in MrBayes (Ronquist et al. 2012), assuming a GTR+G+I model. Interspecific $p$-distances were calculated in MEGA X (Kumar et al. 2018). 


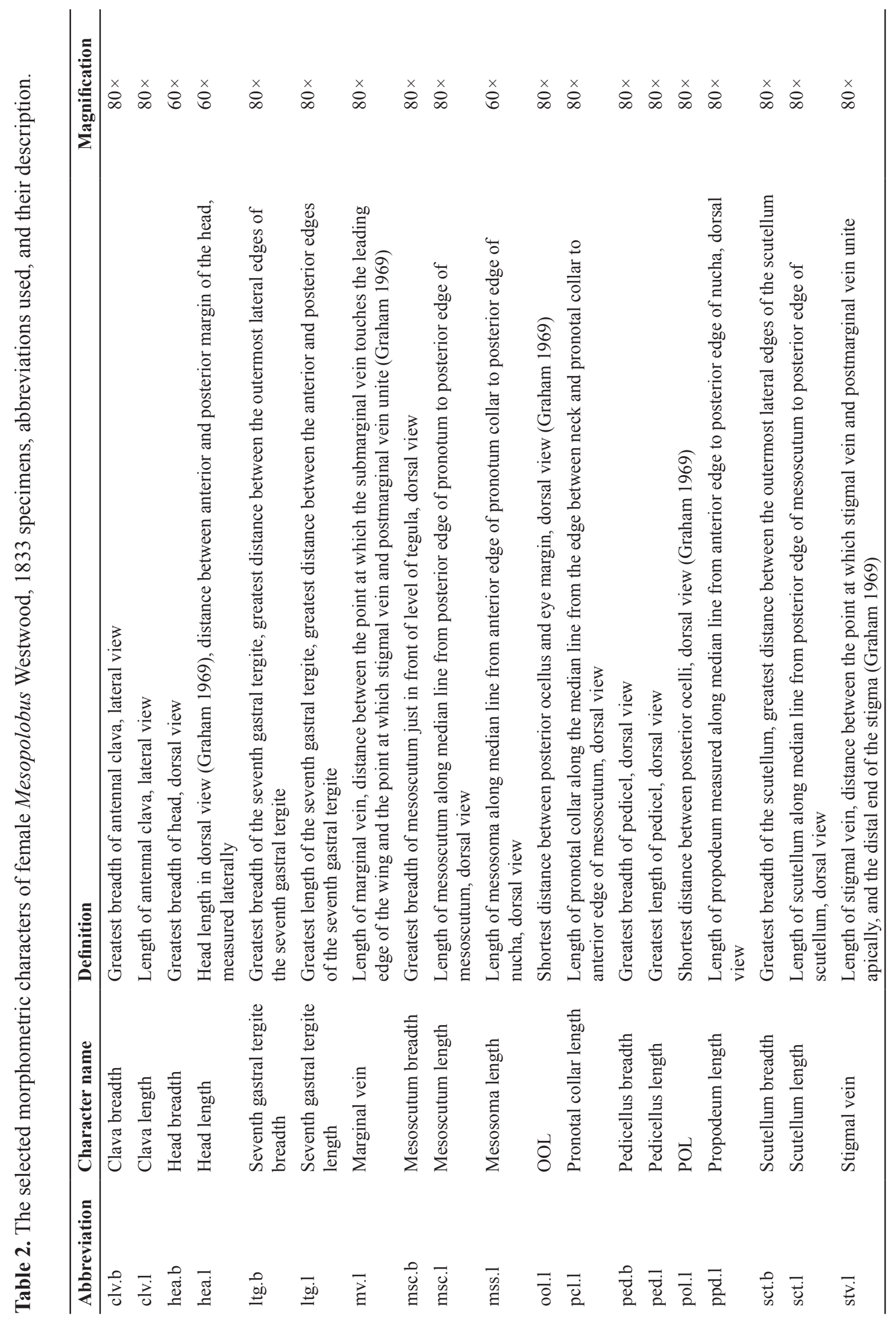




\section{Results}

\section{Multivariate Ratio Analysis of variation in body size and shape}

We first performed a series of shape PCAs on all specimens based on 19 morphometric characters. We identified principal components contributing to morphometric variation of all Mesopolobus females without prior species-determination by applying the PCA in isometry free shape space function to all specimens as a single group. Then we applied the PCA in isometry free shape space only to the group of females which were closest to those emerged from black locust seedpods. When we included all females in shape space, PC1 and PC2 accounted for $58 \%$ of the variation of the entire sampled population. When analysing only those species pairs which were closest to our target group in shape space, PC1 and PC2 accounted for $61 \%$ and $74 \%$ of the variation respectively. The first principal components are congruent with the separation of species, although a clear cut between the clusters could not be established (Fig. 1). On the first scatterplot (Fig. 1a) only five species (M. amaenus, M. verditer, M. sericeus (Förster, 1770), M. typographi and Mesopolobus robiniae Lakatos \& László sp. nov.) showed a clear separation from the rest, but because of the overplotting with Mesopolobus robiniae sp. nov. we also retained $M$. fasciiventris for further analyses. On the other two scatterplots (Fig. 1b-c) the selected species show almost clear separations on PC1, while on PC2 are overlapping.

The PCA ratio spectrum for the species pair M. amaenus and M. robiniae sp. nov. (Fig. 2a) identified ltg.l at the extreme high end, and stv.l at the extreme low end of the spectrum. These characters were also found to contribute to species discrimination. The allometry ratio spectrum for the first species pair was dominated almost by the same ratio, stv.l and ltg.l (Fig. 2b), which is also the most important ratio concerning the first shape PC which shows to be the most allometric one. The PCA ratio spectrum for the species pair M. fasciiventris and M. robiniae sp. nov. (Fig. 2c) identified pcl.l at the extreme high end, while stv.l at the extreme low end of the spectrum. These characters, except for stv.l, were found to contribute to species discrimination. The allometry ratio spectrum for the second species pair was dominated almost by the same ratio, pcl.1 and ltg.b (Fig. 2d), that is not the most important ratio concerning the first shape PC.

For the species pair M. amaenus and M. robiniae sp. nov. the LDA ratio extractor identified stv.1/lgt.l and hea.l/stv.l as the first two best discriminating ratios. These two combined ratios successfully separated the two species (Fig. 3a). The calculated ratios for the LDA-suggested characters (M. amaenus vs M. robiniae sp. nov., range, mean, sd) are: stv.1/lgt.1 $(1.38-4.25,2.38,1.21)$ vs $(0.80-1.15,0.92,0.11)$;
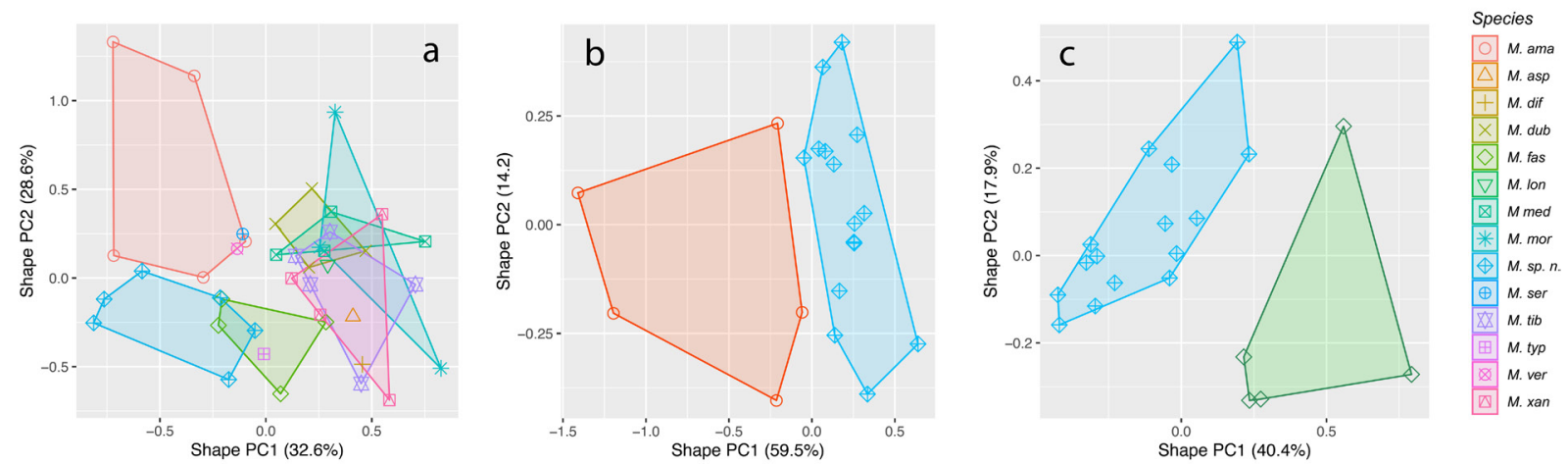

Fig. 1. Scatterplot of first against second shape PC based on 19 morphometric variables of females. a. All 14 species of Mesopolobus Westwood, 1833. b. M. amaenus (Walker, 1834) and Mesopolobus robiniae Lakatos \& László sp. nov. emerged from black locust seedpods. c. M. fasciiventris Westwood, 1833 and Mesopolobus robiniae Lakatos \& László sp. nov. emerged from black locust seedpods. The variance explained by each shape PC is given in parentheses. 
PCA Ratio Spectrum for PC1

Allometry Ratio Spectrum
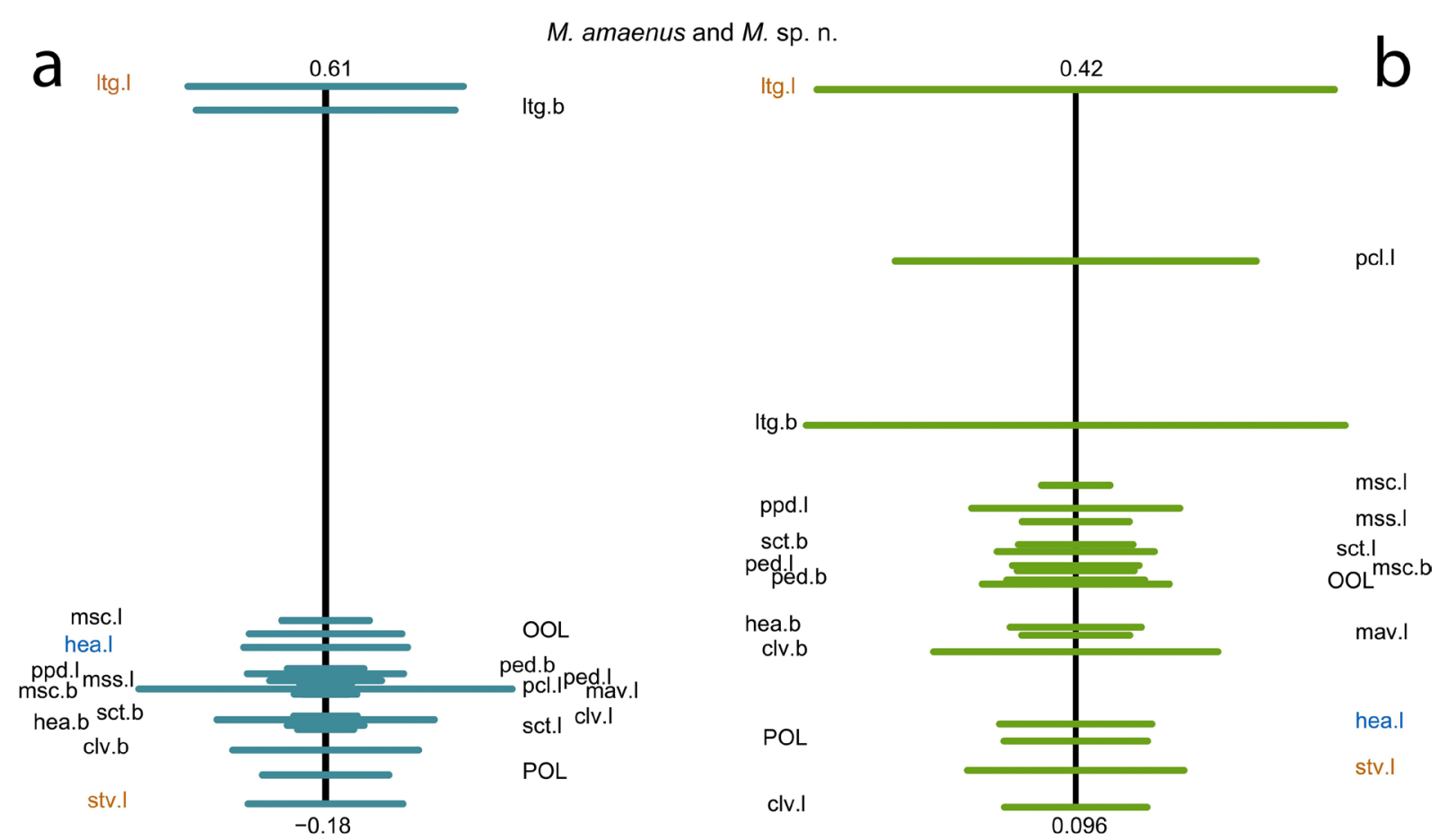

C

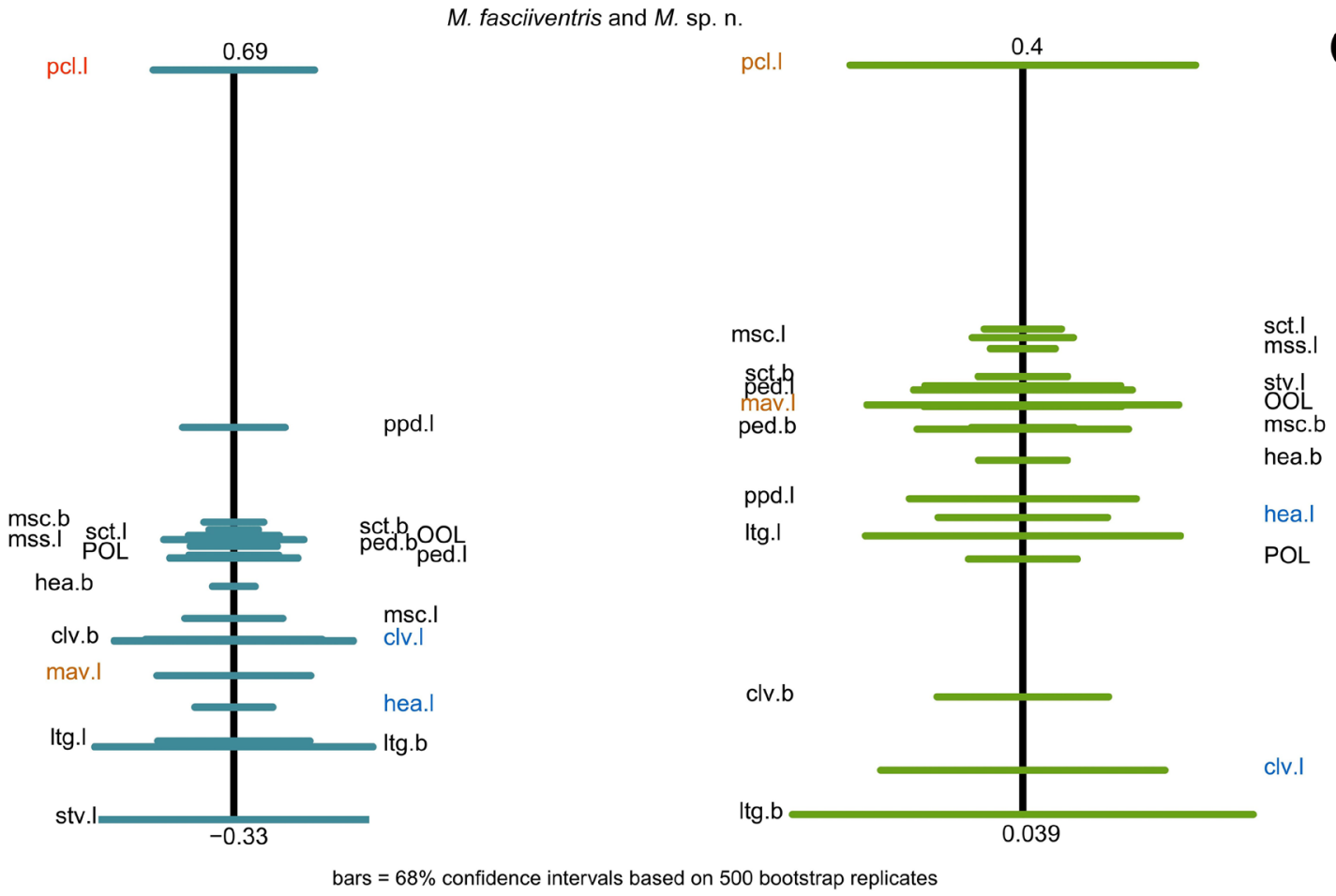

Fig. 2. Ratio spectra for the species pairs. a, c. PCA ratio spectrum. b, d. Allometry ratio spectrum. a. The two species pairs. b. Mesopolobus amaenus (Walker, 1834) and Mesopolobus robiniae Lakatos \& László sp. nov. c-d. M. fasciiventris Westwood, 1833 and Mesopolobus robiniae Lakatos \& László sp. nov. Horizontal bars in the ratio spectra represent $68 \%$ bootstrap confidence intervals based on 1000 replicates. 
hea.1/stv.1 $(0.11-1.12,0.93,0.13)$ vs $(1.11-1.53,1.26,0.11)$. This suggests that the two species can be separated when judgement is based on a series of individuals. Further, the calculated D.shape is much higher than D.size in all of the two best discriminative ratios, indicating that species are mostly separated by differences in shape of characters (Table 3).

For the species pair M. fasciiventris and M. robiniae sp. nov. the LDA ratio extractor identified pcl.1/mav.1 and clv.1/hea.l as the first two best discriminating ratios. These two combined ratios successfully separated the two species (Fig. 3b). The calculated ratios for the LDA-suggested characters ( $M$. fasciiventris vs M. robiniae sp. nov., range, mean, sd) are: pcl.13/mav.l $(0.07-0.10,0.08,0.02)$ vs $(0.11-0.20,0.15$, $0.05)$; clv.1/hea.l $(0.36-0.66,0.50,0.14)$ vs $(0.52-0.68,0.63,0.04)$. This suggests that the two species can be separated when judgement is based on a series of individuals. Further, the calculated D.shape is much higher than D.size in all of the two best discriminative ratios, indicating that species are mostly separated by differences in shape of characters (Table 3 ).

Because specimens of $M$. verditer and M. sericeus were overlapping in the shape PCA with M. amaenus, we calculated the best ratios for discriminating $M$. amaenus from $M$. robiniae sp. nov. for these two species as well. M. typographi overlapped in the shape PCA with M. fasciiventris, so we also calculated the best ratios discriminating $M$. fasciiventris from $M$. robiniae sp. nov. for M. typographi (Table 3).

\section{Molecular species delimitation}

Based on molecular analysis of the available samples, Mesopolobus robiniae sp. nov. is placed closest to Mesopolobus verditer (Norton 1868) (Fig. 4). The three individuals represented only one haplotype (653 bp) that was deposited in GenBank with the MF098549 accession number. The alignment of the downloaded sequences was 468 bp long and consisted of 3 Pteromalus species (used as outgroup) and 14 Mesopolobus species, including the one described in this paper.

The phylogenetic relationship between the species is unresolved based on the available COI sequence data, but the tree shows a well-supported differentiation $(\mathrm{PP}=1)$ of the new species, with $M$. verditer

\section{First and second best ratios}

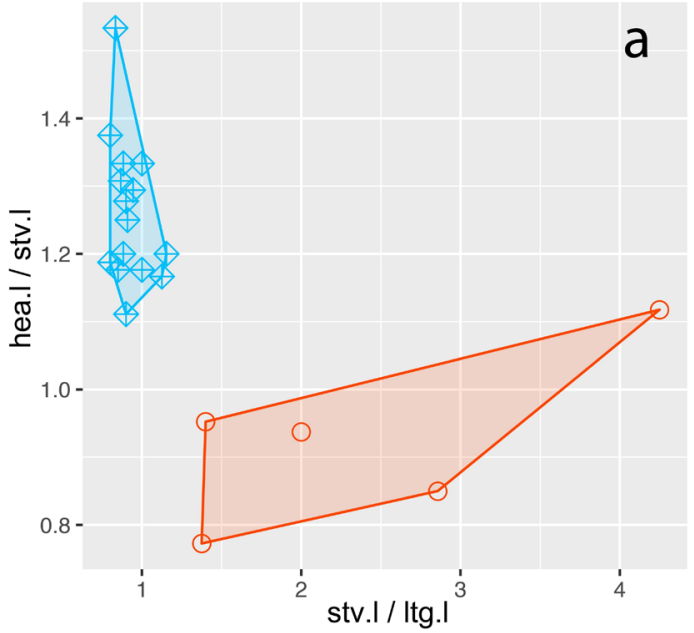

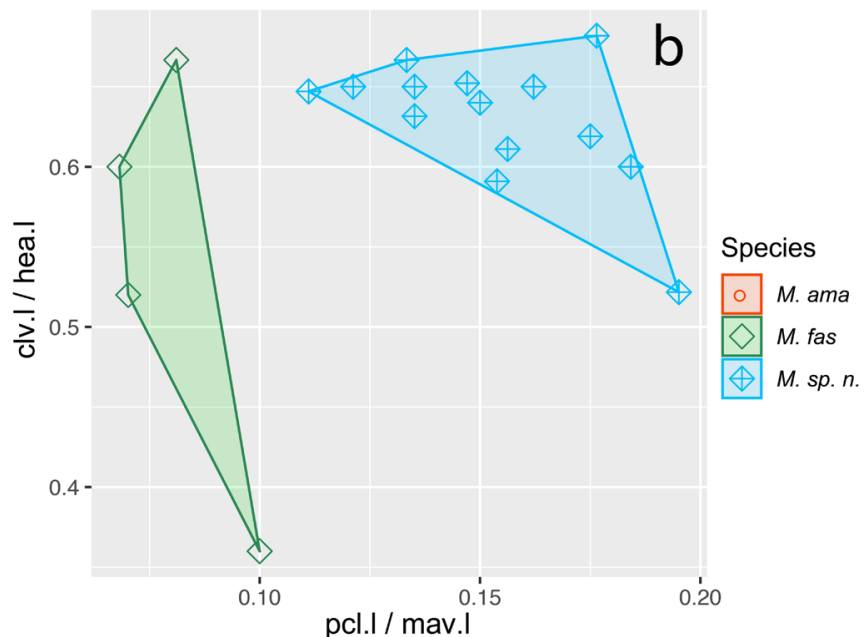

Fig. 3. Scatterplots of the two most discriminating ratios for females. a. Mesopolobus amaenus (Walker, 1834) and Mesopolobus robiniae Lakatos \& László sp. nov. b. M. fasciiventris Westwood, 1833 and Mesopolobus robiniae Lakatos \& László sp. nov. Both plots show first versus second ratio from LDA ratio extract analysis. 
Table 3. First and second-best ratios found by the LDA ratio extractor for separating various groups and specimens of Mesopolobus Westwood, 1833 females.

\begin{tabular}{lccccc}
\hline & Best ratios & $\begin{array}{c}\text { Range } \\
\text { group 1 }\end{array}$ & $\begin{array}{c}\text { Range } \\
\text { group 2 }\end{array}$ & D.shape & D.size \\
\hline Group / species comparison & & & & & \\
M. amaenus vs M. robiniae sp. nov. & stv.1/lgt.1 & $1.38-4.25$ & $0.80-1.15$ & 0.73 & 0.03 \\
& hea.1/stv.1 & $0.11-1.12$ & $1.11-1.53$ & 0.72 & 0.04 \\
M. verditer & stv.1/lgt.1 & $1.91-2.50$ & & & \\
& hea.1/stv.1 & 1.14 & & & \\
M. sericeus & stv.1//gt.1 & 1.41 & & & \\
& hea.1/stv.1 & 1.15 & & & \\
M. fasciiventris vs M. robiniae sp. nov. & pcl.1/mav.1 & $0.07-0.10$ & $0.11-0.20$ & 0.65 & 0.01 \\
& clv.1/hea.1 & $0.36-0.66$ & $0.52-0.68$ & 0.63 & 0.01 \\
M. typographi & pcl.1/mav.1 & 0.1 & & & \\
& clv.1/hea.1 & 0.55 & & & \\
\hline
\end{tabular}

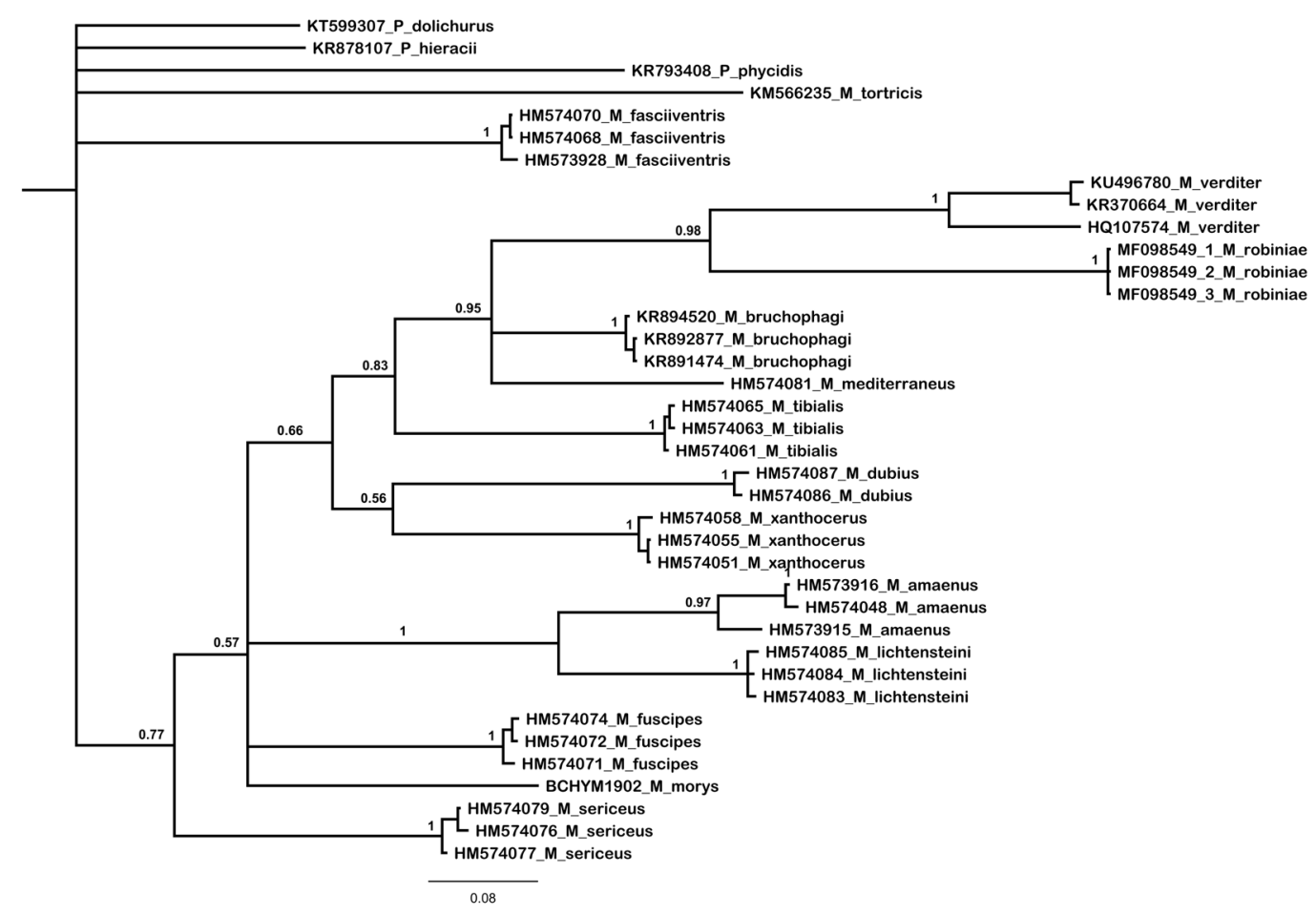

Fig. 4. Bayesian inference (BI) tree of the species of Mesopolobus Westwood, 1833 that have available mitochondrial COI sequences. Numbers on the branches represent posterior probabilities (PP). 


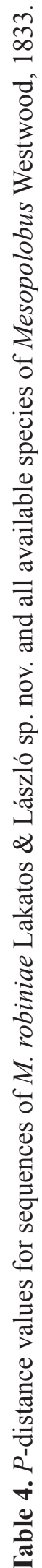

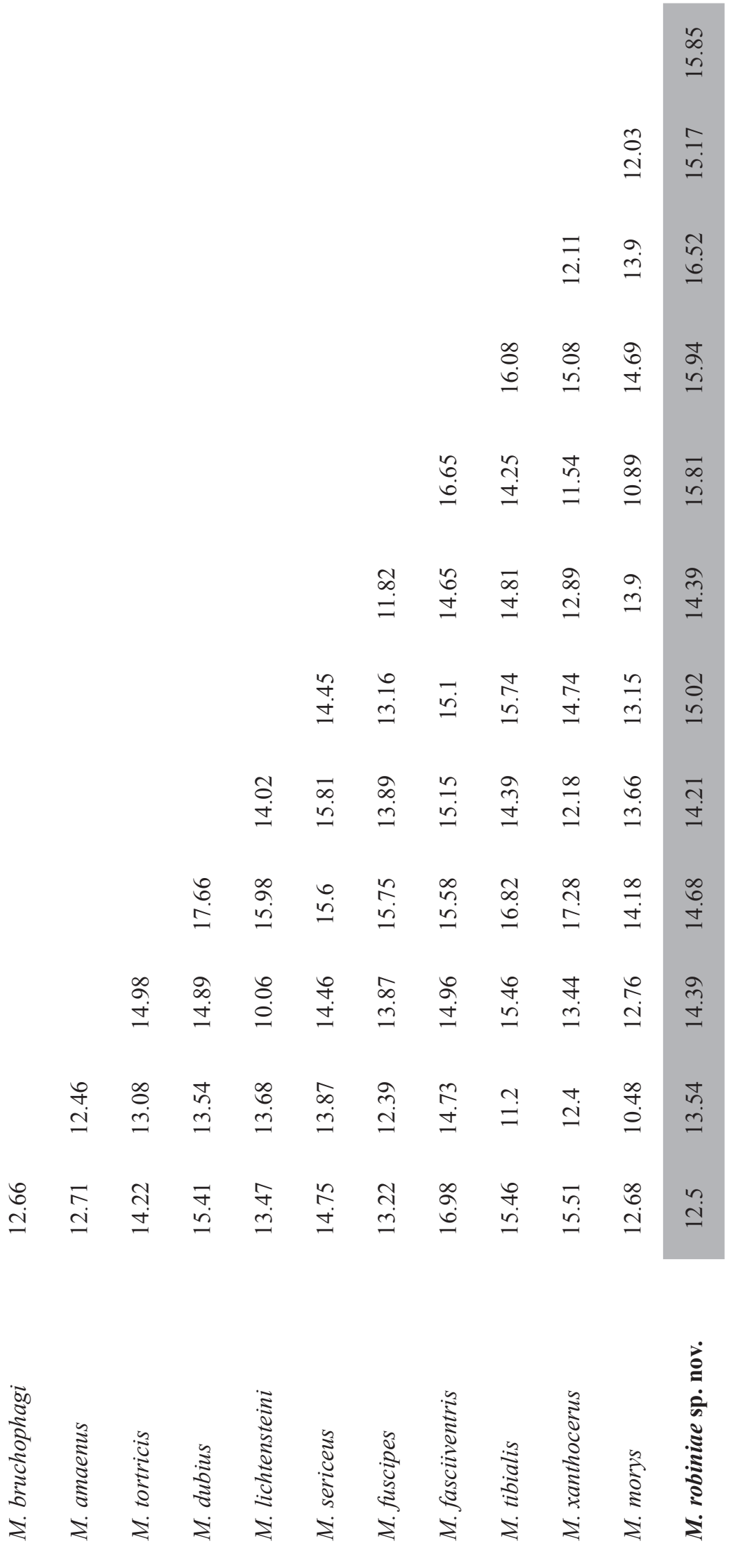


as the closest species (Fig. 4). The differentiation is also supported by the $p$-distance values with a minimum of $12.5 \%$ between M. robiniae sp. nov. and M. verditer, and a maximum of $16.52 \%$ between M. robiniae sp. nov. and M. tibialis (Table 4).

\title{
Taxonomy
}

Class Insecta Linnaeus, 1758

Order Hymenoptera Linnaeus, 1758

Suborder Apocrita Latreille, 1810

Superfamily Chalcidoidea Latreille, 1817

Family Pteromalidae Dalman, 1820

Subfamily Pteromalinae Dalman, 1820

Genus Mesopolobus Westwood, 1833

Mesopolobus Westwood, 1833: 443 (type species: Mesopolobus fasciiventris Westwood, 1833 by monotypy).

\author{
Mesopolobus robiniae Lakatos \& László sp. nov. \\ urn:lsid:zoobank.org:act:9650B871-3BF8-49C8-9329-43A67A3C2D5B
}

Fig. 5

\section{Diagnosis}

Mesopolobus robiniae sp. nov. is characterized by having the following morphological characters: head with uniform reticulation, antennae inserted at or above ventral edge of compound eyes, with three anelli, head broader than mesoscutum, pronotal collar moderately long, marginal vein of fore wing about twice as long as the stigma vein, metasoma longer than mesosoma, with only slightly projecting ovipositor sheaths, body green, antennae proximally testaceous with funiculus and clava infuscate, femora and tibiae testaceous, with hyaline wings. Mesopolobus robiniae sp. nov. differs from closely resembling species by the ratios of metasoma to head plus mesosoma length, of temples to eye length, of marginal to stigma vein, of pronotal collar to mesoscutum length and of antennal clava to head length. Molecular results: the three sequenced individuals represented one haplotype (GenBank accession number: MF098549); based on the BI tree the new species, shows a well-supported differentiation from $M$. verditer as the closest species and from other congenerics with the maximal differentiation from M. tibialis.

\section{Etymology}

The new Mesopolobus species is named after the host plant of its seed predator host, the black locust (Robinia pseudoacacia).

\section{Material examined}

\section{Holotype}

ROMANIA • + ; Bihor County, near Săldăbagiu de Munte; $47.096354^{\circ}$ N, $21.984963^{\circ}$ E; 11 Mar. 2015; T.K. Lakatos leg.; emerged on 1 Apr. 2015; MZBBU HYM000011.

\section{Paratypes}

ROMANIA - Bihor County • 1 ; ; same collection data as for holotype; MZBBU HYM000012 • 1 क ; near Săldăbagiu de Munte; $47.100895^{\circ}$ N, $21.967509^{\circ}$ E; 8 Mar. 2014; T.K. Lakatos leg., emerged on 22 Apr. 2014; MZBBU HYM000017 • 1 क ; near Săldăbagiu de Munte; $47.098182^{\circ}$ N, $21.975352^{\circ}$ E; 11 Mar. 2014; T.K. Lakatos leg.; emerged on 23 Apr. 2014; MZBBU HYM000018 • 2 đో ${ }^{\lambda}$; near Săldăbagiu 
de Munte; $47.098182^{\circ}$ N, $21.975352^{\circ}$ E; 8 Mar. 2014; T.K. Lakatos leg.; emerged on 22 Apr. 2014; MZBBU HYM000019, HYM000020 • 1 đ’; near Săldăbagiu de Munte; $47.079446^{\circ}$ N, $21.970817^{\circ}$ E; 14 Mar. 2009; T.K. Lakatos leg.; emerged on May 2009; MZBBU HYM000021 • 1 ○;; near Săldăbagiu de Munte; 47.098519 ${ }^{\circ}$ N, $21.984808^{\circ}$ E; 11 Mar. 2015; T.K. Lakatos leg., emerged on Apr. 2015; MZBBU HYM000022. - Cluj County • 1 \&; near Cluj-Napoca; $46.777109^{\circ} \mathrm{N}, 23.674495^{\circ} \mathrm{E} ; 17$ Mar. 2015; T.K. Lakatos leg.; emerged on 10 Apr 2015; MZBBU HYM000013 • 1 q; same collection data as for preceding; 18 Mar. 2014; T.K. Lakatos leg.; emerged in May 2014; MZBBU HYM000014 • 2 우; near Cluj-Napoca; $46.768086^{\circ}$ N, 23.568935 ${ }^{\circ}$ E; 17 Mar. 2009; T.K. Lakatos leg.; emerged in Apr. 2009, MZBBU HYM000015, HYM000016 • 1 o; near Cluj-Napoca; 46.834976º N, 23.651004 E; 22 Mar. 2014; T.K. Lakatos leg.; emerged in May 2014; MZBBU HYM000024 • 1 §; near Cluj-Napoca; $46.768086^{\circ} \mathrm{N}, 23.568935^{\circ} \mathrm{E}$; 17 Mar. 2009; T.K. Lakatos leg.; emerged in May 2009; MZBBU HYM000025.

HUNGARY • 1 §ं; Hajdú-Bihar County, near Debrecen; $47.554773^{\circ} \mathrm{N} 21.591610^{\circ} \mathrm{E} ; 2$ Mar. 2015; T.K. Lakatos leg.; emerged on Apr. 2015; MZBBU HYM000023

Other material (specimens used for the genetic analysis)

ROMANIA • 3 + 9 ; Bihor County, near Săldăbagiu de Munte; $47.0968^{\circ}$ N, $21.98525^{\circ}$ E; 13 Mar. 2014; T.K. Lakatos leg.; emerged on 17 Apr. 2014; GenBank accession number: MF098549. This specimens were fully processed for the DNA extraction.

\section{Description}

Female

LeNGTH. 2.05 to $3.00 \mathrm{~mm}(\mathrm{~N}=15$, mean $=2.6, \mathrm{sd}=0.29 \mathrm{~mm})$.

COLORATION. Body green, sometimes with golden reflections; metasoma bronze-black distally, some of the tergites occasionally with blue or violet flecks. Coloration of antennae: scape, pedicellus and anelli testaceous, sometimes last anellus infuscate, all funicular segments and clava infuscate, occasionally brown. Coxae concolorous with the mesosoma, femora and tibiae testaceous, the tips of the fifth tarsi fuscous to black. Tegulae hyaline, usually slightly yellow posteriorly. Wings hyaline; venation pale yellow.

HEAD. 1.1 (range 1.02-1.18) times as broad as mesoscutum; in dorsal view 2.25 (2.07-2.52) times as broad as long, with temples rounded off and between one third and one fourth as long as eyes; the distance between posterior ocelli (POL) 2.11 (1.75-2.80) times oculo-ocellar distance (OOL). Head in front view suboval with the genae moderately buccate. Eyes separated about $1.59(1.18-1.74)$ times their length. Malar space more than half $(0.68(0.55-0.76))$ the length of an eye. Breadth of oral fossa 1.93 (1.69-2.36) times malar space. Clypeus strigose, its anterior margin moderately emarginate. Head uniformly and moderately reticulate. Antennae inserted low on head, lower edge of toruli at or hardly above level of ventral edge of eyes; distance between clypeal margin and toruli $0.69(0.54-0.8)$ times the distance between median ocellus and toruli. Scape length 1.23 (1.09-1.4) times eye length, scape almost reaching lower edge of median ocellus; combined length of pedicellus and flagellum 0.87 (0.76-0.96) times breadth of head; pedicellus (profile) $2.06(0.75-2.5)$ times as long as broad, about as long as anelli plus first funicular segment; flagellum rather weakly clavate, proximally as stout as or slightly

Fig. 5 (opposite page). Mesopolobus robiniae Lakatos \& László sp. nov. a-b, e-f, i. \& (MZBBU

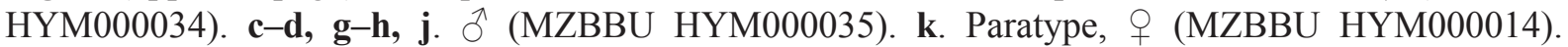

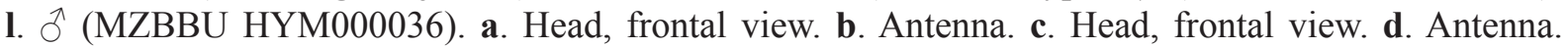
e. Mesosoma. f. Fore wing. g. Mesosoma. h. Fore wing. i. Gaster, dorsal view. j. Gaster, dorsal view. k. Habitus. I. Habitus. Scale bars: $\mathrm{a}-\mathrm{j}=0.1 \mathrm{~mm} ; 1-\mathrm{k}=0.5 \mathrm{~mm}$. 

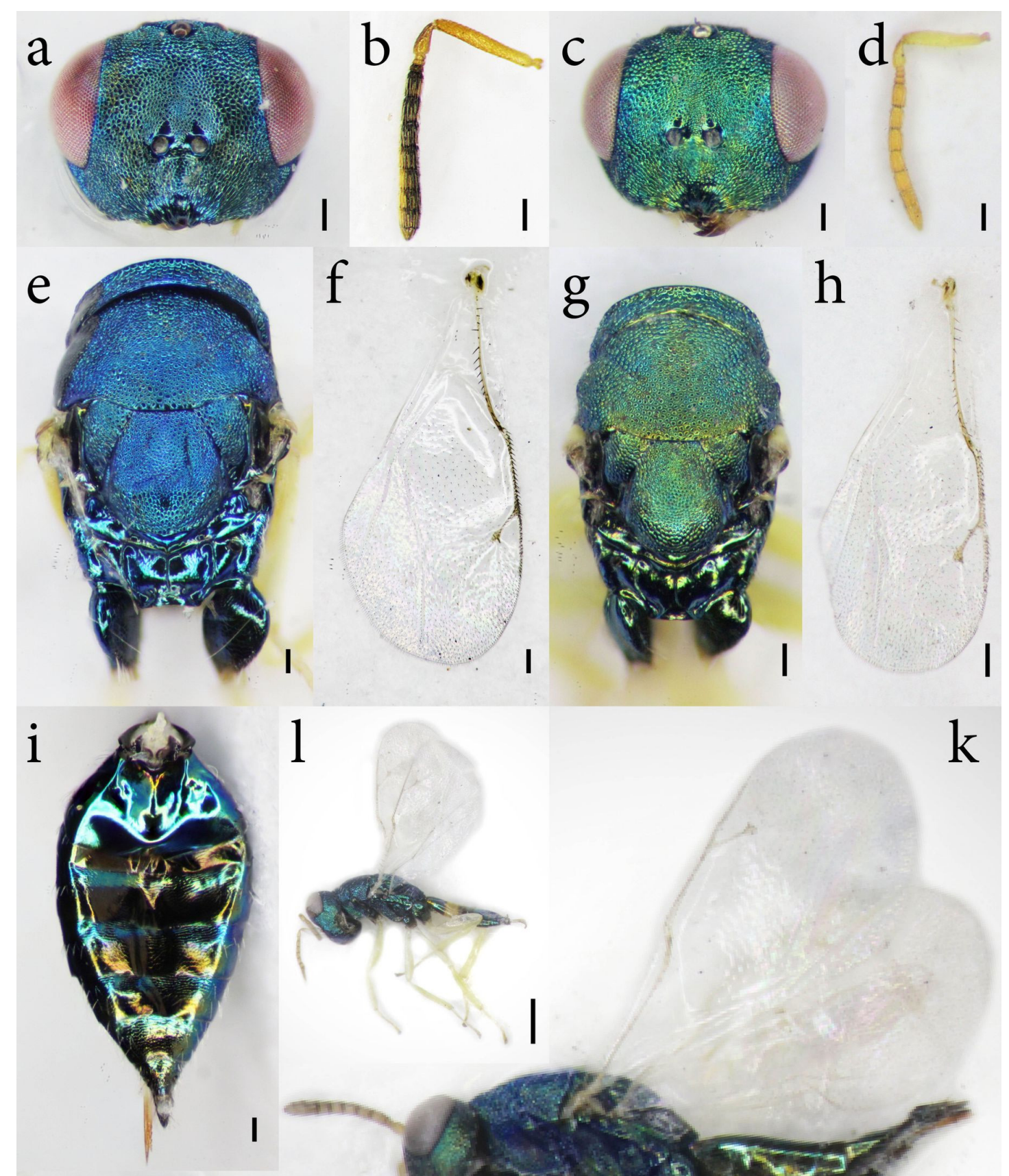

$\mathrm{k}$

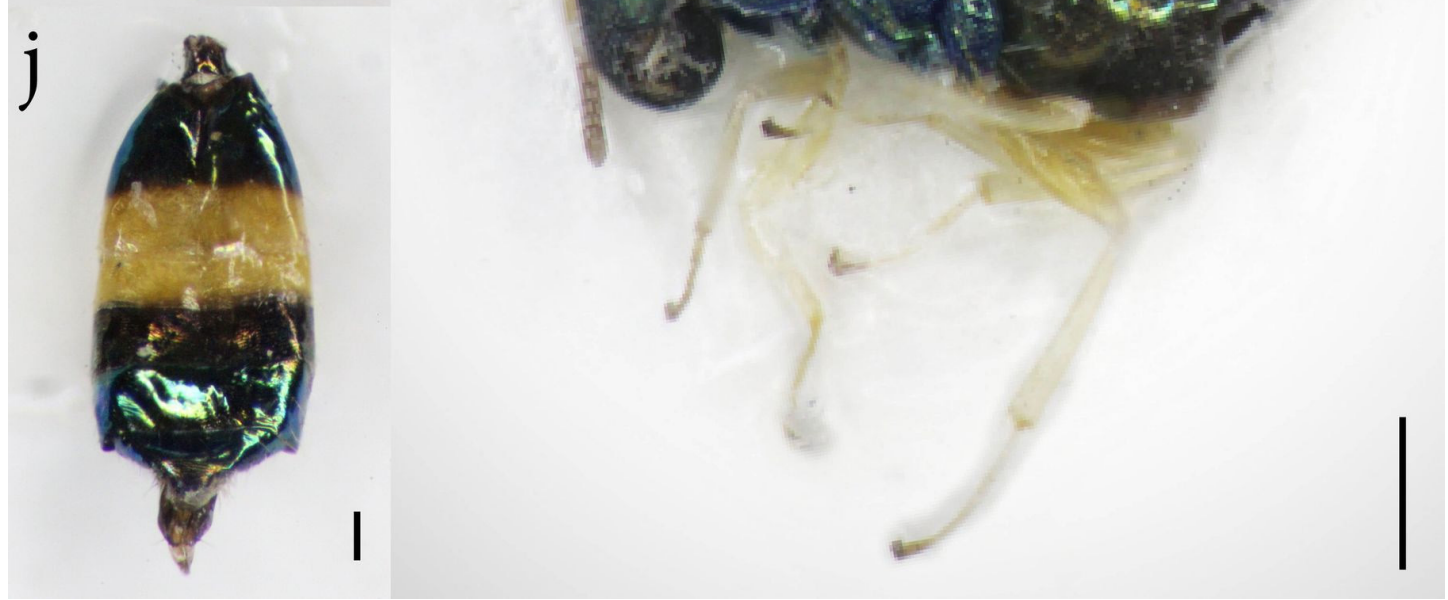


stouter than pedicellus; first and second anelli short, twice or slightly more than twice as broad as long, third anellus longer than previous anellus and about 1.5 times as broad as long; funicular segments subquadrate, proximal ones sometimes slightly longer than broad, distal ones occasionally very slightly transverse; clava $1.9(1.5-2.29)$ times as long as broad, $0.83(0.66-1.15)$ as long as three preceding funicular segments together; sensilla in one row on each segment, sparse on funicle, more numerous on the clava.

Mesosoma. $1.52(1.38-1.74)$ times as long as broad. Pronotal collar moderately long medially, 0.21 (0.16-0.26) times (one sixth to one fifth) as long as mesoscutum, and much longer at sides, strongly and coarsely reticulate, clearly margined. Mesoscutum 1.58 (1.28-1.82) times as broad as long, rather coarsely reticulate discally, more finely laterally, without piliferous punctures. Scutellum $0.9(0.82-0.94)$ times as broad as long, moderately convex, finely reticulate, frenum slightly more coarsely reticulate. Axillae finely reticulate. Dorsellum a narrow, alutaceous transverse crest separated from scutellum by simple suture. Propodeum medially slightly less than half $(0.41(0.36-0.48))$ as long as scutellum; median area 2.39 (2-3) times as broad as long, well-defined laterally, plicae distinct throughout and sharp over at least their distal half; median carina distinct, straight; panels of median area finely, slightly irregularly reticulate; nucha transversely aciculate, separated from median area by impressed line; posterior foveae, at sides of nucha, moderately deep; spiracles oval, longer than broad, separated by nearly half their length from metanotum. Postspiracular sclerite broad, shiny, weakly and irregularly sculptured. Mesepisternum moderately finely reticulate, its upper triangular area smooth; mesepimeron rather more coarsely reticulate than mesepisternum, metapleuron smooth. Legs rather short; femora rather stout; mid tibiae fairly slender, $7.44(4.88-9)$ times as long as their maximum breadth. Fore wing rather broad; costal cell fairly broad, its upper surface bare, lower surface with a complete row of hairs and some additional hairs scattered over distal third to half; basal cell bare, open below; basal vein bare or with one to three hairs; speculum open below, on upper surface of wing extending below proximal end of the marginal vein; surface beyond speculum thickly pilose; marginal vein 2.19 (2-2.47) times as long as stigmal vein; postmarginal vein shorter than marginal, $0.73(0.63-0.81)$ times as long as marginal.

Metasoma. Ovate, $1.24(1.16-1.33)$ times as long as mesosoma, $0.8(0.66-0.96)$ times as broad as mesosoma, 2.37 (1.91-2.96) times as long as broad; basal tergite occupying from slightly more than one quarter to nearly one third of total length; last tergite somewhat shorter than basal breadth, its length 1.07 (0.72-1.79) times its breadth; ovipositor sheaths projecting at most very slightly; hypopygium slightly reaching the middle of metasoma, ratio of hypopygium length to metasoma length is $0.44(0.35-0.54)$.

\section{Male}

LENGTH. 1.8 to $2.25 \mathrm{~mm}(\mathrm{~N}=15$, mean $=2.02, \mathrm{sd}=0.16 \mathrm{~mm})$.

Coloration. Head and mesosoma bright green; metasoma greenish dorsally with second tergite (T2) and posterior half of first tergite (TI) yellow, third tergite (T3) purplish; antennae bright testaceous; legs except coxae yellow, last tarsal segments grey-brown.

HEAD. Antenna with 3 anelli and 5 funicular segments, length of pedicel plus flagellum 0.97 (0.85-1.04) times as breadth as head; scape 5.33 (4.6-6.25) times as long as broad, without a boss on its anterior surface; flagellum proximally not broader than pedicel, F1-F4 longer than broad, F5 subquadrate. Mouthparts unmodified; no patch of modified sculpture behind malar sulcus.

Mesosoma. Pronotal collar as long as in females, about $0.21(0.18-0.27)$ times mesoscutal length. Middle tibiae unmodified, $7.42(6.29-8.8)$ times its breadth, tibial spur $1.47(1.17-1.8)$ times breadth of first tarsus. 
Metasoma. Oblong, ovate, $0.91(0.83-1.02)$ times as long as mesosoma, 2.24 (1.63-2.63) times as long as broad with a yellow ventral plica; T1 with triangular depression at base.

\section{Morphological comparison}

Females of Mesopolobus robiniae sp. nov. were not identifiable based on Graham's keys (Graham 1969), but several morphologically and morphometrically related species were found for which the differing characters will be enumerated in the order that the species appear in Graham's key. The species $M$. robiniae sp. nov. has a shorter metasoma compared to head plus mesosoma in M. maculicornis. The species M. jucundus (Walker, 1834) has a curved stigmal vein compared to M. robiniae sp. nov. Mesopolobus robiniae sp. nov. differs from $M$. fasciiventris by its males having 3 anelli and 5 funicular segments while in the latter there are 2 anelli and 6 segments. Females of M. robiniae sp. nov. differ from those of $M$. fasciiventris in the ratios of pcl.13/mav.1 and clv.1/ hea.l (for abbreviations see Table 2, for differences Table 3). The head of M. apicalis in dorsal view has temples nearly three quarters as long as the eyes, while $M$. robiniae sp. nov. has its head in dorsal view with temples appearing one quarter to one third as long as the eyes. The metasoma of M. amaenus is less than twice as long as broad and almost as long as the mesosoma, while in the case of $M$. robiniae sp. nov. the metasoma is not less than twice as long as broad, but it is as long as the mesosoma. The species M. longicollis has the pronotal collar $1 / 7$ to $1 / 6$ as long as the mesoscutum and its metasoma is less than twice as long as broad compared to M. robiniae sp. nov. The species $M$. diffinis and M. meditteraneus differ from M. robiniae sp. nov. because the latter has longer marginal vein (1.4 to 1.6$)$ than length of the stigmal vein.

The species M. verditer is not present in the keys of Graham (1969) because it has a North American distribution. It differs from $M$. robiniae sp. nov. in the following: antennal funicle segments shorter than their breadth, while in $M$. robiniae sp. nov. they are at least as long as their breadth. The ratio of the stigmal vein to the last gastral tergite length is $1.91-2.50$ in $M$. verditer, while in M. robiniae sp. nov. is between 0.08-1.15. Mesopolobus sericeus differs from M. robiniae sp. nov. first by having 2 anelli and 6 funicular segments, but also in having the ratio of the stigmal vein to the last gastral tergite length 1.41, while in the other species this ratio is smaller (0.8-1.15). In M. typographi the median area of the propodeum is 1.75-2 times as broad as long (Graham 1969) while in M. robiniae sp. nov. is $0.82-0.94$ times as broad as long $(\mathrm{N}=15)$.

Based on von Rosen's key (von Rosen 1958), the morphological identification of specimens led us to M. mediterraneus as the closest species, from which females of M. robiniae sp. nov. differs, apart from the previously mentioned longer marginal than stigmal vein, in also having a longer pronotal collar and a shorter metasoma than the combined length of head and mesosoma.

Gahan (1932: 739) states that Mesopolobus (syn. Amblymerus) verditer (Norton 1868) “...conforms very closely to the characters of the genus Amblymerus Walker as represented by Amblymerus amoenus Walker..." (syn. M. amaenus), when transferring the species to the genus Amblymerus Walker, 1834 from the genus Nasonia Ashmead, 1904. The hosts of M. verditer are usually sawflies (Hymenoptera: Diprionidae) on pines (Pinus sp.) (Noyes 2020). Mesopolobus verditer is distributed in the Nearctic and Germany (Thompson 1958). Moreover, M. verditer differs from M. robiniae sp. nov. in having a reticulated middle area of propodeum and oblique wrinkles, as does also from M. amaenus and M. longicollis (von Rosen 1958). 
We propose the following update to the key of Mesopolobus species of Graham (1969) for females:

16. Either metasoma at least slightly longer than head plus mesosoma, and usually more than twice as long as broad, or metasoma not longer than head plus mesosoma, and at most twice as long as broad $16 \mathrm{~A}$

- Metasoma not longer than head plus mesosoma, their ratio is 0.94 (0.88-0.98), metasoma usually more than twice, 2.37 (1.91-2.96) times as long as broad

M. robiniae Lakatos \& László sp. nov.

16A. Metasoma at least slightly longer than head plus mesosoma, usually more than twice as long as broad

- Metasoma not longer than head plus mesosoma, at most twice as long as broad 27

\section{Distribution}

The type locality for M. robiniae sp. nov. is Săldăbagiu de Munte, Bihor County, Romania $\left(47.096354^{\circ}\right.$ N, $21.984963^{\circ} \mathrm{E}$ ). The other localities are situated in the neighbouring counties: Cluj County, Romania and Hajdú-Bihar County, Hungary. The species may appear in the Carpathian Basin where its host plant is present, but we expect that it may also be found outside of the Carpathian Basin, in Eastern Europe and maybe throughout Europe.

\section{Biology}

Based on our rearing, M. robiniae sp. nov. seems to be an early flying parasitoid species. Individuals of the species emerged during spring consequently in all study years. Our black locust seedpod samples were collected mostly in March, and the emergence peak of M. robiniae sp. nov. was in April, with a decrease in May. After May, we rarely encountered any individuals of this parasitoid species.

The host of M. robiniae sp. nov. may be Bruchophagus robiniae but there is no information regarding the host plant of $B$. robiniae before the introduction of black locust. Another possibility is that M. robiniae sp. nov. initially had another host, but switched from it to B. robiniae. Either possibility is plausible; before 1970 (Zerova 1970) the species B. robiniae was not known, and M. robiniae sp. nov. was not described until now. The parasitoid community of black locust is understudied, and the available literature makes no mention of parasitoids in this community (Farkas \& Terpó-Pomogyi 1974; Perju 1998), with the exception of our ecological study concerning the seed-predator community of black locust in Eastern Europe (Lakatos et al. 2016).

\section{Discussion}

The multivariate ratio analysis (MRA) and the $m t$ DNA sequence analysis resulted in the successful separation of the Mesopolobus species emerging from black locust seedpods from the other congeneric relatives. The morphometry-based shape PCA helped us identify which species fall closer to the specimens emerged from black locust crops. This delimitation was important since the available specific keys (Graham 1969) did not lead us to a closest relative based on the combination of morphology and morphometry.

In a PCA ratio spectrum, only ratios calculated with variables lying at the opposite ends of the spectrum are relevant for a particular shape PC and the most allometric ratios are also found at the opposite ends of the allometry ratio spectrum (Baur et al. 2014) we apply multivariate ratio analysis (MRA). The PCA ratio spectrum and the allometry ratio spectrum plots revealed a large (M. amaenus and M. robiniae sp. nov.) and moderate (M. fasciiventris and M. robiniae sp. nov.) amount of allometric variation in the identified discriminating morphometric character pairs (Fig. 2). However, this is not of concern in our 
case, because on the one hand the species we found to be closely related based on morphometry were clearly separated based on the molecular results, and the combinations of the usually used ratios do not overlap with species in the keys of Graham (1969), since there is no possibility to progress beyond key couplet 16. On the other hand, the ratios found with the LDA ratio extractor tool have small D.size values compared to D.shape values (Table 3 ) which means that separation was mainly due to shape rather than size. The LDA ratio extractor tool found that the species pairs could be separated without overlapping based on the first ratio pairs. These ratios in combination with morphologic characters gave a confident separation of the closely related species.

The origin of M. robiniae sp. nov. is as yet unknown, since it has to be a host shifting species. Black locust was introduced to Europe 300 years ago, and in its native area it has no Bruchophagus seed predator, nor the associated parasitoids (Stone 2009). So, the new Mesopolobus species may not be monophagous on B. robiniae, which is similarly a host-shifting seed predator. Nonetheless, it is befitting of the name robiniae, since parasitoids are also affected by the host plant of their herbivorous host. As part of their host finding strategy, parasitoids may search for a specific plant or plant part (as seedpods) housing any potential herbivorous host species (Cronin \& Abrahamson 2001).

\section{Acknowledgments}

We thank to Zoltán Vas, curator of the Hymenoptera collection, Hungarian Natural History Museum for loaning several specimens of various Mesopolobus species and for his valuable help during identification and manuscript preparation. We are thankful to Natalie Dale-Skey, curator of the Hymenoptera section, Natural History Museum, London for loaning several Mesopolobus specimens and to James Hogan Collections Manager of the Hope Entomological Collections, Oxford University Museum of Natural History for providing photography of M. longicollis. We are also thankful to Lajos Király for his help in the molecular analysis. The authors are grateful to Chris Looney (Washington State Department of Agriculture, Olympia, United States) for his review, comments and suggestions of the manuscript. Molecular analysis was done at the Interdisciplinary Research Institute on Bio-Nano-Sciences of BBU, Cluj, Romania. During preparation of the manuscript A.L. Dénes received financial support from the Collegium Talentum scholarships, Hungary.

\section{References}

Askew R.R. 1961. A study of the biology of species of the genus Mesopolobus (Hymenoptera: Pteromalidae) associated with cynipid galls on oak. Transactions of the Royal Entomological Society of London 113 (8): 155-173. https://doi.org/10.1111/j.1365-2311.1961.tb00806.x

Baur H. \& Leuenberger C. 2011. Analysis of ratios in multivariate morphometry. Systematic Biology 60 (6): 813-825. https://doi.org/10.1093/sysbio/syr061

Baur H., Muller F.J., Gibson G.A.P., Mason P.G. \& Kuhlmann U. 2007. A review of the species of Mesopolobus (Chalcidoidea: Pteromalidae) associated with Ceutorhynchus (Coleoptera: Curculionidae) host-species of European origin. Bulletin of Entomological Research 97 (4): 387-397. https://doi.org/10.1017/S0007485307005032

Baur H., Kranz-Baltensperger Y., Cruaud A., Rasplus J.Y., Timokhov A.V. \& Gokhman V.E. 2014. Morphometric analysis and taxonomic revision of Anisopteromalus Ruschka (Hymenoptera: Chalcidoidea: Pteromalidae) - an integrative approach. Systematic Entomology 39 (4): 691-709. https://doi.org/10.1111/syen.12081

Benesperi R., Giuliani C., Zanetti S., Gennai M., Mariotti Lippi M., Guidi T., Nascimbene J. \& Foggi B. 2012. Forest plant diversity is threatened by Robinia pseudoacacia (black-locust) invasion. Biodiversity and Conservation 21 (14): 3555-3568. https://doi.org/10.1007/s10531-012-0380-5 
Bouček Z. \& Rasplus J.-Y. 1991. Illustrated Key to West-Palearctic Genera of Pteromalidae (Hymenoptera: Chalcidoidea). Institut national de la Recherche agronomique (INRA), Paris.

Cronin J. \& Abrahamson W.G. 2001. Do parasitoids diversify in response to host-plant shifts by herbivorous insects? Ecological Entomology 26 (4): 347-355.

https://doi.org/10.1046/j.1365-2311.2001.00332.x

DAISIE 2009. Handbook of Alien Species in Europe. Springer, Dordrecht. https://doi.org/10.1007/978-1-4020-8280-1

Dickie I.A., Bennett B.M., Burrows L.E., Nuñez M.A., Peltzer D.A., Porté A., Richardson D.M., Rejmánek M., Rundel P.W. \& van Wilgen B.W. 2014. Conflicting values: ecosystem services and invasive tree management. Biological Invasions 16 (3): 705-719.

https://doi.org/10.1007/s10530-013-0609-6

Doganlar M. 1979. Two new species of Mesopolobus Westwood (Hymenoptera: Pteromalidae) from western Canada. The Canadian Entomologist 111 (6): 649-659. https://doi.org/10.4039/Ent111649-6

Enescu C.M. \& Dănescu A. 2013. An invasive neophyte in the conventional land reclamation flora in Romania. Bulletin of the Transilvania University of Braşov Series II: Forestry, Wood Industry, Agricultural Food Engineering 6 (55) (2): 23-30.

Farkas K. \& Terpó-Pomogyi M. 1974. A new species of the Hungarian fauna: Bruchophagus robiniae (Hymenoptera, Eurytomidae). Növényvédelem (Plant Protection) 10 (11): 507-508.

Folmer O., Black M., Hoeh W., Lutz R. \& Vrijenhoek R. 1994. DNA primers for amplification of mitochondrial cytochrome c oxidase subunit I from diverse metazoan invertebrates. Molecular Marine Biology and Biotechnology 3 (5): 294-299.

Gahan A.B. 1932. Miscellaneous descriptions and notes on parasitic Hymenoptera. Annals of the Entomological Society of America 25 (4): 736-757. https://doi.org/10.1093/aesa/25.4.736

Graham M.W.R. de V. 1969. The Pteromalidae of North-Western Europe. Bulletin of the British Museum (Natural History) Entomology Suppl. 16: 1-909.

Hall T. 1999. BioEdit: a user-friendly biological sequence alignment editor and analysis program for Windows 95/98/NT. Nucleic Acids Symposium Series 41: 95-98.

Hanzelka J. \& Reif J. 2015. Responses to the black locust (Robinia pseudoacacia) invasion differ between habitat specialists and generalists in central European forest birds. Journal of Ornithology 156 (4): 1015-1024. https://doi.org/10.1007/s10336-015-1231-4

Johnson M., Zaretskaya I., Raytselis Y., Merezhuk Y., McGinnis S. \& Madden T.L. 2008. NCBI BLAST: a better web interface. Nucleic Acids Research 36 (Web Server issue): 5-9.

https://doi.org/10.1093/nar/gkn201

Kleinbauer I., Dullinger S., Peterseil J. \& Essl F. 2010. Climate change might drive the invasive tree Robinia pseudacacia into nature reserves and endangered habitats. Biological Conservation 143 (2): 382-390. https://doi.org/10.1016/j.biocon.2009.10.024

Kumar S., Stecher G., Li M., Knyaz C. \& Tamura K. 2018. MEGA X: Molecular Evolutionary Genetics Analysis across computing platforms. Molecular Biology and Evolution 35 (6): 1547-1549.

https://doi.org/10.1093/molbev/msy096

Lakatos K.T., László Z. \& Tóthmérész B. 2016. Resource dependence in a new ecosystem: a host plant and its colonizing community. Acta Oecologica 73: 80-86. https://doi.org/10.1016/j.actao.2016.03.003

Lakatos K.T., László Z. \& Tóthmérész B. 2018. Disturbance induced dynamics of a tritrophic novel ecosystem. Bulletin of Entomological Research 108 (2): 158-165.

https://doi.org/10.1017/S0007485317000621 
Lazzaro L., Mazza G., D’Errico G., Fabiani A., Giuliani C., Inghilesi A.F., Lagomarsino A., Landi S., Lastrucci L., Pastorelli R., Roversi P.F., Torrini G., Tricarico E. \& Foggi B. 2018. How ecosystems change following invasion by Robinia pseudoacacia: insights from soil chemical properties and soil microbial, nematode, microarthropod and plant communities. Science of the Total Environment 622623: 1509-1518. https://doi.org/10.1016/j.scitotenv.2017.10.017

Narendran T.C., Khan F.R. \& Akhtar M.S. 2011. On a new species of Mesopolobus Westwood (Hymenoptera: Pteromalidae ) from India with a key to the Indian species. Oriental Insects 45 (2-3): 127-131. https://doi.org/10.1080/00305316.2011.590641

Nieves-Aldrey J.L. 1983. Sobre las especies del género Mesopolobus (Hym. Pteromalidae) asociadas con agallas de cinípidos en Quercus spp en Salamanca. Boletín de la Asociación española de Entomología 7: 9-18. Available from http://www.entomologica.es/publicaciones-boletin/art206 [accessed 17 Feb. 2021].

Norton E. 1868. Catalogue of the described Tenthredinidæ and Uroceridæ of North America. (Continued). Transactions of the American Entomological Society (1867-1877) 2: 321-368. https://doi.org/10.2307/25076221

Noyes J. 2020. Universal Chalcidoidea Database. Available from http://www.nhm.ac.uk/chalcidoids [accessed 17 Feb. 2021].

Perju T. 1998. The pest of the white acacia (Robinia pseudoacacia L.). Buletin de Informare Societatea Lepidopterologica Romana 9 (3-4): 291-295.

Pujade-Villar J. 1993. Especies de Mesopolobus (Hym., Pteromalidae) asociadas a agallas de Cynipini (Hym., Cynipidae) del nordeste ibérico y notas sobre la validez de M. lichtensteini (Mayr, 1903). Eos: Revista española de Entomología 69 (1): 63-73.

Available from http://hdl.handle.net/10261/174605 [accessed 17 Feb. 2021].

R Core Team 2020. R: A Language and Environment for Statistical Computing. R Foundation for Statistical Computing, Vienna, Austria. Available from https://www.R-project.org/ [accessed 18 Mar. 2021].

Redei K., Osváth-Bujtás Z. \& Balla I. 2001. Propagation methods for black locust (Robinia pseudoacacia L.) improvement in Hungary. Journal of Forestry Research 12 (4): 215-219. https://doi.org/10.1007/bf02856710

Ronquist F., Teslenko M., Van Der Mark P., Ayres D.L., Darling A., Höhna S., Larget B., Liu L., Suchard M.A. \& Huelsenbeck J.P. 2012. MrBayes 3.2: Efficient bayesian phylogenetic inference and model choice across a large model space. Systematic Biology 61 (3): 539-542.

https://doi.org/10.1093/sysbio/sys029

Sádlo J., Vítková M., Pergl J. \& Pyšek P. 2017. Towards site-specific management of invasive alien trees based on the assessment of their impacts: the case of Robinia pseudoacacia. NeoBiota 35: 1-34. https://doi.org/10.3897/neobiota.35.11909

Stone K.R. 2009. Robinia pseudoacacia. In: Fire Effects Information System (FEIS) [Online]. U.S. Department of Agriculture, Forest Service, Rocky Mountain Research Station, Fire Sciences Laboratory. Available from https://www.fs.fed.us/database/feis/plants/tree/robpse/all.html [accessed 1 May 2020].

Thompson J.D., Higgins D.G. \& Gibson T.J. 1994. Clustal W: improving the sensitivity of progressive multiple sequence aligment through sequence weighting, position specific gap penalties and weight matrix choice. Nucleic Acids Research 22 (22): 4673-4680. https://doi.org/10.1093/nar/22.22.4673

Thompson W.R. 1958. A Catalogue of the Parasites and Predators of Insect Pests. Commonwealth Agricultural Bureaux, Commonwealth Institute of Biological Control, Ottawa, Ontario, Canada. 
Vítková M., Müllerová J., Sádlo J., Pergl J. \& Pyšek P. 2017. Black locust (Robinia pseudoacacia) beloved and despised: a story of an invasive tree in Central Europe. Forest Ecology and Management 384: 287-302. https://doi.org/10.1016/j.foreco.2016.10.057

von Rosen H. 1958. Zur Kenntnis des Pteromaliden-Genus Mesopolobus Westwood, 1833 (Hym., Chalc.). Opuscula Entomologica 23 (3): 203-240.

von Rosen H. 1959. Zur Kenntnis der Pteromaliden-Genus Mesopolobus Westwood 1833 (Hym., Chalcidoidea) IV. Entomologisk Tidskrift 80 (3/4): 146-162.

von Rosen H. 1960. Zur Kenntnis des Pteromaliden-Genus Mesopolobus Westwood 1833 (Hym., Chalc.) VI. Opuscula Entomologica 25: 16-29.

von Rosen H. 1961. Zur Kenntnis der Pteromaliden-Genus Mesopolobus Westwood 1833 Hym. Chalc. Anzeiger für Schädlingskunde 34 (4): 62-62.

Westwood J.O. 1833. LXXIII. Descriptions of several new British forms amongst the parasitic hymenopterous insects. The London, Edinburgh, and Dublin Philosophical Magazine and Journal of Science Series 32 (12): 443-445. https://doi.org/10.1080/14786443308648084

Xiao H., Sun L., Jiao T. \& Li Z. 2016. A revision of Chinese species of Mesopolobus Westwood (Hymenoptera: Pteromalidae) with descriptions of four new species from China. Zoological Systematics 41 (1): 64-81. https://doi.org/10.11865/zs.201604

Zerova M.D. 1970. A new species of the genus Bruchophagus Ashm. (Hymenoptera, Eurytomidae) from the south part of the USSR. Vestnik Zoologii 5: 77-79. [in Russian.]

Manuscript received: 21 September 2020

Manuscript accepted: 10 December 2020

Published on: 26 March 2021

Topic editor: Nesrine Akkari

Topic editor: Gavin Broad

Desk editor: Pepe Fernández

Printed versions of all papers are also deposited in the libraries of the institutes that are members of the EJT consortium: Muséum national d'histoire naturelle, Paris, France; Meise Botanic Garden, Belgium; Royal Museum for Central Africa, Tervuren, Belgium; Royal Belgian Institute of Natural Sciences, Brussels, Belgium; Natural History Museum of Denmark, Copenhagen, Denmark; Naturalis Biodiversity Center, Leiden, the Netherlands; Museo Nacional de Ciencias Naturales-CSIC, Madrid, Spain; Real Jardín Botánico de Madrid CSIC, Spain; Zoological Research Museum Alexander Koenig, Bonn, Germany; National Museum, Prague, Czech Republic.

Supp. file 1: Morphometric measurements of dry-mounted Mesopolobus Westwood, 1833 females belonging to the analysed species. https://doi.org/10.5852/ejt.2021.740.1285.3849 